\title{
The Effect of Giving Bio Fertilizer and Foliar Fertilizer on the Growth and Yield of Celery (Apium graviolens)
}

\author{
Wiwik Yunidawati ${ }^{1}$, Riyanti ${ }^{2}$, Mazlina $^{3}$ \\ ${ }^{1,2,3}$ Department of Agrotechnology, Faculty of Agriculture, Universitas Amir Hamzah, Medan, Indonesia \\ eliakim_purba@yahoo.com
}

\begin{abstract}
This study aims to determine the effect of bio fertilizers and foliar fertilizers on growth and yield of celery (Apium graviolens). This research was conducted at the Experimental Garden of the Faculty of Agriculture, Amir Hamzah University, Medan, Medan Estate Village, Percut Sei Tuan District with a height of \pm 25 meters above sea level, which was conducted from May to July 2020. This study used a factorial Randomized Block Design with two factors studied, namely the first factor was the concentration of bio fertilizer Impro Tanotec $(H)$, which consisted of 4 levels, namely $\mathrm{HO}(0 \mathrm{ml} / \mathrm{water}), \mathrm{H} 1$ (1,5 $\mathrm{ml} / \mathrm{l}$ water $), \mathrm{H} 2$ (2,5 $\mathrm{ml} / \mathrm{water}), \mathrm{H} 3$ (3,5 $\mathrm{ml} / \mathrm{water})$, and the second factor is the concentration of foliar fertilizer Growmore (D) which consists of 4 levels, namely DO (0 gr/lwater), D1 (1 gr/l water), D2 (2 gr/l water), and D3 (3 gr/l water). Parameters observed included plant height $(\mathrm{cm})$, number of leaves, number of stalks, root length $(\mathrm{cm})$, and fresh weight per plant. ( $\mathrm{gr})$. The results showed that the concentration of bio fertilizer had a very significant effect on plant height at the age of 20,40, and 60 days after planting, the number of leaves at the age of 20, 40, and 60 days after planting, the number of stalks at the age of 40 and 60 days after planting, root length, and fresh weight per plant, but did not significantly affect the number of stalks at the age of 20 days after planting. The best bio-fertilizer concentration was obtained in the $\mathrm{H} 3$ treatment $(3.5 \mathrm{ml} / \mathrm{l}$ water). The concentration of foliar fertilizer had a very significant effect on plant height at the age of 20,40, and 60 days after planting, the number of leaves at the age of 20,40, and 60 days after planting, the number of stalks at the age of 40 and 60 days after planting, and the fresh weight per plant, had a significant effect on root length, and had no significant effect on the number of stalks at the age of 20 days after planting. The best foliar fertilizer concentration was obtained in D3 treatment ( $3 \mathrm{gr} / \mathrm{l}$ water). The interaction between the concentration of bio fertilizer and foliar fertilizers had a significant effect on the number of leaves at the age of 40 and 60 days after planting, where the best treatment combination was obtained in the H3D3 treatment (bio fertilizer concentration $3.5 \mathrm{ml} / \mathrm{l}$ water and foliar fertilizer concentration $3 \mathrm{gr} / \mathrm{l}$ water).
\end{abstract}

Keywords: bio fertilizer; foliar fertilizer; concentration; celery

\section{Introduction}

Celery has been known for thousands of years in Europe as a medicinal ingredient and a food flavoring. Plinius Tua has been writing since the beginning of the modern calendar. Linnaeus described the first celery plant in the agricultural edition of the Species Plantarum. He entered the celery plant into the Umbelliferae tribe, which is now called Apiaceae (adasadasan tribe) (Sunarjono, 2011).

Basically, the prospect of celery is very promising, both in the domestic market (domestic) and abroad as an export commodity, but celery cultivation in Indonesia is generally still on a small scale as a side activity. Some evidence about celery cultivation in Indonesia that has not been managed commercially, among others, can refer to data from the Central Statistics Agency regarding the results of a survey of vegetable farming in Indonesia in 2008, apparently no data on harvest area and national celery production have not been found. Likewise in the horticultural research and development program in Indonesia at the Research and Development Center (Puslitbang). Horticulture until 2003/2004, it turns out that 
celery has not received research priority, either as a main, potential or introduced commodity (Sutrisna, 2005 in Sundari, 2012).

In general, the problem that is often faced by celery farmers in Indonesia is cultivation technology, starting from selecting seeds, planting, fertilizing, and controlling pests and diseases. Most farmers in Indonesia still use very simple farming methods and are only done carelessly, especially in the use of fertilizers that only use chemical fertilizers.

One of the cultivation techniques that play a role in increasing celery production is fertilization. For good growth and yield, this plant requires complete nutrients, both macro and micro, with a balanced composition supplied by fertilizer. Therefore, efforts to increase celery production must be done. One way of increasing production is by improving cultivation techniques such as the use of bio fertilizers and foliar fertilizers.

According to Saraswati (2012) in Noegraha (2015), bio fertilizer is a useful microorganism material to increase soil fertility and the quality of plant yields, through increased biological activity that can interact with the physical and chemical properties of plant growing media.The advantages of using bio fertilizers are to increase fertilization efficiency and to increase yields and sustainability, and improve fertility and soil and plant health. One of the organic fertilizers currently on the market is Impro Tanotec.

Impro tanotec biological powder fertilizer is a bio fertilizer from selected ingredients that are processed using superior microorganisms, namely Bacillus Pantotkentikus, Trichoderma Lactae, and Bacillus firmus, as an activator, and contains humus, organic acids, enzymes and growth hormones for other useful microorganisms such as Azotobacter, Pseudomonas and Penicillium (Bagus, 2011).

In addition to the use of bio fertilizers, application of foliar fertilizers is a very beneficial action for the application of micro nutrients because in addition to providing large amounts of $\mathrm{N}, \mathrm{P}$ and $\mathrm{K}$ elements, foliar fertilizers also contain micro nutrients needed in small amounts including $\mathrm{Fe}, \mathrm{Mn}, \mathrm{Br}, \mathrm{Zn}$, and Mo (Pinus and Marsono, 2007). One of the foliar fertilizers currently on the market is Growmore 32-10-10.

Growmore $32-10-10$ is a complete foliar fertilizer in the form of blue crystals, very soluble in water. Growmore 32-10-10 contains levels of N: 32\%, P205: 10\%, K20: $10 \%$, equipped with the elements of $\mathrm{Mn}, \mathrm{B}, \mathrm{Cu}, \mathrm{S}, \mathrm{Co}, \mathrm{Zn}, \mathrm{Fe}, \mathrm{Mo}$ (Suharja, 2012).

\section{Materials and Method}

This research was conducted at the Experimental Garden of the Faculty of Agriculture, Amir Hamzah University, Medan with a height of $\pm 25 \mathrm{~m}$ above sea level with a flat topography. This research was conducted from May to July 2020.

The materials used in this study were celery seedlings, Impro Tanotec biological fertilizer, Growmore 32-10-10 foliar fertilizer, top soil, manure, polybags for planting with a size of $20 \times 35 \mathrm{~cm}$, Insecticide Decis 2,5 EC, Fungicide Dithane. M-45 80 WP, raffia rope, nails, spray paint, nameplate, treatment board and plot board.The tools used in this study were sickle, hoe, rake, machete, tape measure, ruler, handsprayer, gembor, digital scales, sitting scales, calculators, leaf fertilizer measuring instruments, writing instruments and cameras.

This study used a factorial Randomized Block Design (RBD) consisting of two factors, namely:

The first factor: Concentration of Impro Tanotec bio fertilizer $(\mathrm{H})$ consists of 4 levels:

$$
\begin{aligned}
& \mathrm{H}_{0}=0 \mathrm{ml} / \mathrm{l} \text { water } \\
& \mathrm{H}_{1}=1.5 \mathrm{ml} / 1 \text { water } \\
& \mathrm{H}_{2}=2.5 \mathrm{ml} / 1 \text { water } \\
& \mathrm{H}_{3}=3.5 \mathrm{ml} / 1 \text { water }
\end{aligned}
$$


The second factor: Concentration of Growmore foliar fertilizer (D) consists of 4 levels: $\mathrm{D}_{0}=0 \mathrm{gr} / \mathrm{l}$ water
$\mathrm{D}_{1}=1 \mathrm{gr} / \mathrm{l}$ water
$\mathrm{D}_{2}=2 \mathrm{gr} / \mathrm{l}$ water
$\mathrm{D}_{3}=3 \mathrm{gr} / \mathrm{l}$ water

Thus obtained 16 treatment combinations for each treatment was repeated 2 (two) times, in order to obtain 32 experimental units.

The mathematical model used in this study (Adji, 2007) is:

Where :

$$
\mathbf{Y}_{\mathbf{i j k}}=\mu+\boldsymbol{\beta}_{\mathbf{i}}+\mathbf{H}_{\mathbf{j}}+\mathbf{D}_{\mathbf{k}}+(\mathbf{H D})_{\mathbf{j k}}+\varepsilon_{\mathbf{i j k}}
$$

$\mathbf{Y}_{\mathbf{i j k}}=$ Observation results obtained from the concentration of bio fertilizers at level $j$ and the concentration of foliar fertilizers at level $k$ in block $i$

$\boldsymbol{\mu} \quad=$ Mean

$\boldsymbol{\beta}_{\mathrm{i}} \quad=$ Effect of block $\mathrm{i}(\mathrm{i}=1$ and2)

$\mathbf{H}_{\mathrm{j}} \quad=$ Effect of bio fertilizer concentration at level $j(\mathrm{j}=0,1,2$ and 3$)$

$\mathbf{D}_{\mathbf{k}} \quad=$ Effect of foliar fertilizer concentration at level $k(\mathrm{k}=0,1,2$ and 3$)$

$(\mathbf{H D})_{\mathbf{j k}}=$ The effect of the interaction between the concentration of bio fertilizers at level $\mathrm{j}$ and the concentration of foliar fertilizers at level $\mathrm{k}$.

$\varepsilon_{\mathbf{i j k}}=$ The effect of error from the treatment of bio fertilizer concentration level $\mathbf{j}$ and foliar fertilizers concentration level $\mathrm{k}$, in block-i

Data from each experiment will be analyzed by means of variance ( $\mathrm{F}$ test) at the $5 \%$ and $1 \%$ levels. Parameters that have a very real or significant effect on the $F$ test will be followed by the Least Significant Difference Test (LSD) at the 5\% level.

Parameters observed included plant height $(\mathrm{cm})$, number of leaves, number of stalks, root length $(\mathrm{cm})$, and fresh weight per plant $(\mathrm{gr})$.

\section{Results and Discussion}

\subsection{Effect of Bio Fertilizer on Growth and Yield of Celery}

\section{a. Plant Height}

The results of the analysis of variance showed that the application of bio fertilizers had a very significant effect on plant height at the age of 20 days after planting, 40 days after planting and 60 days after planting. The average height of celery plants at the age of 20 days after planting, 40 days after planting and 60 days after planting due to the application of bio fertilizers is presented in Table 1 below.

Table 1. Average Height of Celery Plants at the Age of 20 Days After Planting, 40 Days After Planting and 60 Days After Planting Due to Bio Fertilizer

\begin{tabular}{|c|c|c|c|}
\hline \multirow{2}{*}{$\begin{array}{l}\text { Concentration of } \\
\text { Bio fertilizer }\end{array}$} & \multicolumn{3}{|c|}{ Plant height $(\mathrm{cm})$} \\
\hline & $\begin{array}{l}20 \text { days sfter } \\
\text { planting }\end{array}$ & $\begin{array}{l}40 \text { days after } \\
\text { planting }\end{array}$ & $\begin{array}{l}60 \text { days after } \\
\text { planting }\end{array}$ \\
\hline $\mathrm{H}_{0}$ & $4.96 \mathrm{a}$ & $7.54 \mathrm{a}$ & $10.08 \mathrm{a}$ \\
\hline $\mathrm{H}_{1}$ & $5.93 \mathrm{~b}$ & $8.23 \mathrm{~b}$ & $10.45 \mathrm{a}$ \\
\hline $\mathrm{H}_{2}$ & $6.73 \mathrm{c}$ & $9.10 \mathrm{c}$ & $10.94 \mathrm{~b}$ \\
\hline $\mathrm{H}_{3}$ & $8.16 \mathrm{~d}$ & $10.56 \mathrm{~d}$ & $12.65 \mathrm{c}$ \\
\hline
\end{tabular}

Note: The numbers followed by the same letter in the same column are not significantly different in the LSD test at $5 \%$ level. 
Table 1 shows that the data on the average height of celery plants aged 20, 40 and 60 days after planting due to the highest bio fertilizer treatment was obtained in the $\mathrm{H}_{3}$ treatment followed by $\mathrm{H}_{2}, \mathrm{H}_{1}$ and $\mathrm{H}_{0}$. From the LSD results at the 0.05 level, it is known that the height of celery in treatment $\mathrm{H}_{3}\left(3,5 \mathrm{ml} /\right.$ liter water) significantly different from treatment $\mathrm{H}_{2}$ (2,5ml/iter water), $\mathrm{H}_{1}\left(1,5 \mathrm{ml} /\right.$ liter water) and treatment $\mathrm{H}_{0}$ (Control). It is suspected that Impro Tanotec's bio fertilizer at a dose of $3.5 \mathrm{ml} /$ liter of water is the right dose to provide nutrients so that it can increase the height of celery plants. According to Soepadi, (2001), the ability of the soil to provide nutrients for plants is a major factor in plant growth and production, the availability of sufficient nutrients in the soil will have an effect on plant height increase. Suswati (2020) states that the combination will affect the growing environment such as temperature, humidity and sunlight entering the plant canopy.

\section{b. Number of Leaves}

The results of the analysis of variance showed that the application of bio fertilizers had a very significant effect on the number of leaves of plants aged 20 days after planting, 40 days after planting and 60 days after planting. The average height of celery plants at the age of 20 days after planting, 40 days after planting and 60 days after planting due to the application of bio fertilizers is presented in Table 2 below.

Table 2. Average Number of Celery Leaves at 20 Days After Planting, 40 Days After Planting and 60 Days After Planting Due to Bio Fertilizer

\begin{tabular}{|c|c|c|c|}
\hline \multirow{2}{*}{$\begin{array}{l}\text { Concentration of } \\
\text { Bio fertilizer }\end{array}$} & \multicolumn{3}{|c|}{ Number of Leaves } \\
\hline & $\begin{array}{l}20 \text { days after } \\
\text { planting }\end{array}$ & $\begin{array}{l}40 \text { days after } \\
\text { planting }\end{array}$ & $\begin{array}{c}60 \text { days after } \\
\text { planting }\end{array}$ \\
\hline $\mathrm{H}_{0}$ & $3.44 \mathrm{a}$ & $7.84 \mathrm{a}$ & $11.44 \mathrm{a}$ \\
\hline$\overline{\mathrm{H}_{1}}$ & $4.56 \mathrm{~b}$ & $8.84 \mathrm{~b}$ & $12.66 \mathrm{~b}$ \\
\hline $\mathrm{H}_{2}$ & $6.00 \mathrm{c}$ & $10.59 \mathrm{c}$ & $15.22 \mathrm{c}$ \\
\hline $\mathrm{H}_{3}$ & $7.22 \mathrm{~d}$ & $12.97 \mathrm{~d}$ & $17.44 \mathrm{~d}$ \\
\hline
\end{tabular}

Note: The numbers followed by the same letter in the same column are not significantly different in the LSD test at $5 \%$ level.

Table 2 shows that the average number of leaves of celery plants aged 20 days after planting, 40 days after planting and 60 days after planting due to the highest bio fertilizer treatment was obtained in the $\mathrm{H}_{3}$ treatment followed by $\mathrm{H}_{2}, \mathrm{H}_{1}$ and $\mathrm{H}_{0}$. From the LSD results at the 0.05 level, it is known that the number of celery leaves in treatment $\mathrm{H}_{3}(3.5 \mathrm{~m} / \mathrm{liter}$ water) was significantly different from treatment $\mathrm{H}_{2}(2.5 \mathrm{~m} /$ liter water $), \mathrm{H}_{1}(1.5 \mathrm{~m} /$ /iter water) and $\mathrm{H}_{0}$ treatment (control). It is suspected that Impro Tanotec bio-giving given at a dose of $3.5 \mathrm{~m} /$ /iter of water increased the number of celery leaves. In accordance with the research results of Joko et al. (2010). According to Goenadi in Andrian (2019) Sources of nutrition given to kale with hydroponic planting systems can come from cacao peel waste according to Goenadi et, al (2000) content of $1.81 \% \mathrm{~N}, 26.61 \%$ C-organic, $0.31 \% \mathrm{P} 2 \mathrm{O} 5$, $6.08 \% \mathrm{~K} 2 \mathrm{O}, 1.22 \% \mathrm{CaO}, 1.37 \% \mathrm{MgO}$, and $44.85 \mathrm{cmol} / \mathrm{kg} \mathrm{CEC}$ (kaloit exchange capacity). Bio fertilizer has a very significant effect on the number of plant leaves because the mycorrhizae in organic fertilizers can effectively increase the absorption of nutrients, both macro and micro nutrients. Apart from that, mycorrhizal roots can absorb nutrients in bound form and which are not available to plants, thereby increasing the number of leaves. 


\section{c. Number of Stalks}

The results of the analysis of variance showed that the application of bio fertilizers had a very significant effect on the number of stalks of plants aged 40 days after planting and 60 days after planting. But it has no real effect on the age of 20 days after planting. The average number of celery stalks at the age of 20 days after planting, 40 days after planting and 60 days after planting due to the application of bio fertilizers is presented in Table 3 below.

Table 3. Average Number of Celery Stalks at 20 Days After Planting, 40 Days After Planting and 60 Days After Planting Due to Bio Fertilizer

\begin{tabular}{|c|c|c|c|}
\hline $\begin{array}{c}\text { Concentration of Bio } \\
\text { fertilizer }\end{array}$ & \multicolumn{3}{|c|}{ Number of Stalks } \\
\cline { 2 - 4 } & $\begin{array}{c}\text { 20 days after } \\
\text { planting }\end{array}$ & $\begin{array}{c}40 \text { days after } \\
\text { planting }\end{array}$ & $\begin{array}{c}60 \text { days after } \\
\text { planting }\end{array}$ \\
\hline $\mathrm{H}_{0}$ & 1.56 & $3.22 \mathrm{a}$ & $6.16 \mathrm{a}$ \\
\hline $\mathrm{H}_{1}$ & 1.66 & $3.25 \mathrm{a}$ & $6.13 \mathrm{a}$ \\
\hline $\mathrm{H}_{2}$ & 1.94 & $3.59 \mathrm{a}$ & $6.50 \mathrm{a}$ \\
\hline $\mathrm{H}_{3}$ & 1.91 & $4.16 \mathrm{~b}$ & $7.25 \mathrm{~b}$ \\
\hline
\end{tabular}

Note: The numbers followed by the same letter in the same column are not significantly different in the LSD test at $5 \%$ level.

Table 3 shows that the average number of celery stalks at the age of 20 days after planting, 40 days after planting and 60 days after planting due to the highest biological fertilizer treatment was obtained in the $\mathrm{H}_{3}$ treatment followed by $\mathrm{H}_{2}, \mathrm{H}_{1}$ and $\mathrm{H}_{0}$. From the LSD results at the 0.05 level, it is known that the number of celery stalks in treatment $\mathrm{H}_{3}(3.5$ $\mathrm{ml} /$ liter water) was significantly different from treatment $\mathrm{H}_{2}$ (2.5 m/liter water), $\mathrm{H}_{1}$ (1.5 $\mathrm{m} /$ /iter water) and $\mathrm{H}_{0}$ treatment (Control). It is thought that the increasing dose of biological fertilizers given to the plant will increase the number of nutrients available and absorbed by plants, so that it can spur an increase in the number of celery shoots. Harjadi (2002) also states that the availability of nutrients in sufficient and balanced amounts for plant growth causes the division, enlargement and elongation processes of cells to take place better.

\section{d. Root Length and Fresh Weight Per Plant}

The results of analysis of variance showed that the application of biological fertilizers had a very significant effect on root length and fresh weight per plant. The average root length and fresh weight per plant of celery due to the application of bio fertilizers are presented in Table 4 below.

Table 4. Average Root Length and Fresh Weight Per Celery Plant Due to Bio Fertilizer

\begin{tabular}{|c|c|c|}
\hline $\begin{array}{c}\text { Concentration of Bio } \\
\text { fertilizer }\end{array}$ & Root Length (cm) & Fresh Weight Per Plant (gr) \\
\hline $\mathrm{H}_{0}$ & $5.05 \mathrm{a}$ & $11.98 \mathrm{a}$ \\
\hline $\mathrm{H}_{1}$ & $5.86 \mathrm{ab}$ & $14.78 \mathrm{~b}$ \\
\hline $\mathrm{H}_{2}$ & $6.30 \mathrm{~b}$ & $15.06 \mathrm{~b}$ \\
\hline $\mathrm{H}_{3}$ & $7.51 \mathrm{c}$ & $17.70 \mathrm{c}$ \\
\hline
\end{tabular}

Note: The numbers followed by the same letter in the same column are not significantly different in the LSD test at $5 \%$ level.

Table 4 shows that the data on average root length and fresh weight per celery plant due to the highest biological fertilizer treatment were obtained in the $\mathrm{H}_{3}$ treatment followed by $\mathrm{H}_{2}$, $\mathrm{H}_{1}$ and $\mathrm{H}_{0}$. From the LSD results at the 0.05 level, it was known that the root length and fresh weight per celery plant in the $\mathrm{H}_{3}$ treatment $(3.5 \mathrm{~m} /$ liter water $)$ were significantly different from the $\mathrm{H}_{2}$ (2.5 ml/liter water), $\mathrm{H}_{1}\left(1.5 \mathrm{ml} /\right.$ liter of water) and $\mathrm{H}_{0}$ treatment (Control). It is 
suspected that giving Impro Tanotec bio fertilizer at a dose of $3.5 \mathrm{ml} / \mathrm{liter}$ of water is the right dose to increase root length so that it can absorb nutrients that can increase fresh weight per plant. Sutedjo (2002) stated that plants will not provide maximum growth results if the nutrients needed are lacking and normal plant growth is obtained when adequate and balanced nutrient availability in the soil.

\subsection{The Effect of Foliar Fertilizer on the Growth and Yield of Celery Plants a. Plant Height}

The results of the analysis of variance showed that the concentration of foliar fertilizer Growmore had a very significant effect on plant height at the age of 20 days after planting, 40 days after planting and 60 days after planting. The average height of celery at the age of 20 days after planting, 40 days after planting and 60 days after planting due to the concentration of foliar fertilizer Growmore is presented in Table 5 below.

Table 5. Average Height of Celery Plants at the Age of 20 Days After Planting, 40 Days After Planting and 60 Days After Planting due to Foliar Fertilizer Growmore Concentrations

\begin{tabular}{|c|c|c|c|}
\hline \multirow{2}{*}{$\begin{array}{c}\text { Concentration of } \\
\text { Foliar Fertilizer }\end{array}$} & \multicolumn{3}{|c|}{ Plant height $(\mathrm{cm})$} \\
\cline { 2 - 4 } & $\begin{array}{c}\text { 20 Days After } \\
\text { Planting }\end{array}$ & $\begin{array}{c}\text { 40 Days After } \\
\text { Planting }\end{array}$ & $\begin{array}{c}\text { 60 Days After } \\
\text { Planting }\end{array}$ \\
\hline $\mathrm{D}_{0}$ & $5.48 \mathrm{a}$ & $7.76 \mathrm{a}$ & $10.13 \mathrm{a}$ \\
\hline $\mathrm{D}_{1}$ & $6.19 \mathrm{~b}$ & $8.70 \mathrm{~b}$ & $10.82 \mathrm{~b}$ \\
\hline $\mathrm{D}_{2}$ & $6.62 \mathrm{~b}$ & $9.09 \mathrm{~b}$ & $11.18 \mathrm{~b}$ \\
\hline $\mathrm{D}_{3}$ & $7.48 \mathrm{c}$ & $9.88 \mathrm{c}$ & $11.98 \mathrm{c}$ \\
\hline
\end{tabular}

Note: The numbers followed by the same letter in the same column are not significantly different in the LSD test at $5 \%$ level.

Table 5 shows that the data on the average height of celery plants aged 20 days after planting, 40 days after planting and 60 days after planting due to the treatment of the highest foliar fertilizer growmore concentration was obtained in the $\mathrm{D}_{3}$ treatment ( 3 gr/liter of water) followed by $\mathrm{D}_{2}$ ( $2 \mathrm{gr} /$ liter of water), $\mathrm{D}_{1}\left(1 \mathrm{~g} /\right.$ liter of water) and $\mathrm{D}_{0}$ (Control). From the LSD results at the 0.05 level, it is known that the height of celery in treatment $\mathrm{D}_{3}$ is significantly different from treatment $D_{2}, D_{1}$ and treatment $D_{0}$. This shows that celery plants given foliar fertilizer at a dose of $3 \mathrm{gr} /$ liter of water is the right dose to produce higher plant height. According to Dwidjoseputro (1991), plants will thrive if the nutrients they need are available in sufficient and balanced quantities. Suharja, (2012) added that Growmore 32-10-10 is a complete foliar fertilizer in the form of blue crystals, very easy to dissolve in water. Growmore 32-10-10 contains levels of N: 32\%, P205: 10\%, K20: 10\%, equipped with the elements $\mathrm{Mn}, \mathrm{B}, \mathrm{Cu}, \mathrm{S}, \mathrm{Co}, \mathrm{Zn}, \mathrm{Fe}, \mathrm{Mo}$.

\section{b. Number of Leaves}

The results of the analysis of variance showed that the concentration of foliar fertilizer growmore had a very significant effect on the number of leaves of plants aged 20 days after planting, 40 days after planting and 60 days after planting. The average number of leaves of celery at the age of 20 days after planting, 40 days after planting and 60 days after planting due to the concentration of foliar fertilizer growmore is presented in Table 6 below.

Table 6. Average Number of Celery Leaves at 20 Days After Planting, 40 Days After Planting and 60 Days After Planting Due to Concentrationof Foliar Fertilizer Growmore

\begin{tabular}{|c|c|c|c|}
\hline Concentration of & \multicolumn{3}{|c|}{ Number of Leaves } \\
\cline { 2 - 4 } Foliar Fertilizer & $\begin{array}{c}20 \text { days after } \\
\text { planting }\end{array}$ & $\begin{array}{c}40 \text { days after } \\
\text { planting }\end{array}$ & $\begin{array}{c}60 \text { days after } \\
\text { planting }\end{array}$ \\
\hline
\end{tabular}




\begin{tabular}{|c|c|c|c|}
\hline $\mathrm{D}_{0}$ & $4.13 \mathrm{a}$ & $8.44 \mathrm{a}$ & $12.03 \mathrm{a}$ \\
\hline $\mathrm{D}_{1}$ & $5.06 \mathrm{~b}$ & $10.00 \mathrm{~b}$ & $14.03 \mathrm{~b}$ \\
\hline $\mathrm{D}_{2}$ & $5.66 \mathrm{c}$ & $10.22 \mathrm{~b}$ & $14.38 \mathrm{~b}$ \\
\hline $\mathrm{D}_{3}$ & $6.38 \mathrm{~d}$ & $11.59 \mathrm{c}$ & $16.31 \mathrm{c}$ \\
\hline
\end{tabular}

Note: The numbers followed by the same letter in the same column are not significantly different in the LSD test at $5 \%$ level.

Table 6 shows that the average number of leaves of celery plants aged 20 days after planting, 40 days after planting and 60 days after planting due to the treatment of the highest concentrationof foliar fertilizer growmore was obtained in treatment $\mathrm{D}_{3}$ (3 gr/liter of water) followed by $\mathrm{D}_{2}$ (2 gr/liter of water), $\mathrm{D}_{1}$ ( 1 gr/liter of water) and $\mathrm{D}_{0}$ (Control). From the LSD results at the 0.05 level, it is known that the number of celery leaves in treatment $\mathrm{D}_{3}$ was significantly different from treatment $\mathrm{D}_{2}, \mathrm{D}_{1}$ and treatment $\mathrm{D}_{0}$.It is suspected that by giving foliar fertilizer at a dose of $3 \mathrm{gr} /$ liter of water is an appropriate dose so that the nitrogen element in the plant is available so that it can play a direct role in spurring the increase in leaf growth, according to Sutedjo (2002), adding Nitrogen is the main nutrient for growth, which generally indispensable for the growth or development of vegetative parts such as roots, stems and leaves.

\section{c. Number of Stalks}

The results of analysis of variance showed that the concentration of foliar fertilizer growmore had a very significant effect on the number of stalks of plants aged 40 and 60 days after planting. But it has no real effect on the age of 20 days after planting. The average number of celery stalks at the age of 20 days after planting, 40 days after planting and 60 days after planting due to the concentration of foliar fertilizer growmore is presented in Table 7 below.

Table 7. Average Number of Celery Stalks at the Age of 20 Days After Planting, 40 Days After Planting and 60 Days After Planting Due to Concentrations of Foliar Fertilizer Growmore

\begin{tabular}{|c|c|c|c|}
\hline $\begin{array}{c}\text { Concentrations of } \\
\text { Foliar Fertilizer }\end{array}$ & \multicolumn{3}{|c|}{ Number of Stalks } \\
\cline { 2 - 4 } & $\begin{array}{c}\text { 20 Days After } \\
\text { Planting }\end{array}$ & $\begin{array}{c}\text { 40 Days After } \\
\text { Planting }\end{array}$ & $\begin{array}{c}\text { 60 Days After } \\
\text { Planting }\end{array}$ \\
\hline $\mathrm{D}_{0}$ & 1.75 & $3.03 \mathrm{a}$ & $5.81 \mathrm{a}$ \\
\hline $\mathrm{D}_{1}$ & 1.69 & $3.47 \mathrm{a}$ & $6.47 \mathrm{~b}$ \\
\hline $\mathrm{D}_{2}$ & 1.72 & $3.53 \mathrm{a}$ & $6.56 \mathrm{~b}$ \\
\hline $\mathrm{D}_{3}$ & 1.91 & $4.19 \mathrm{~b}$ & $7.19 \mathrm{c}$ \\
\hline
\end{tabular}

Note: The numbers followed by the same letter in the same column are not significantly different in the LSD test at $5 \%$ level.

Table 7 shows that the data on the average number of celery stalks aged 40 days after planting and 60 days after planting due to the treatment of the highest concentration of foliar fertilizer growmore was obtained in treatment $\mathrm{D}_{3}$ (3 gr/liter water) followed by $\mathrm{D}_{2}$ ( 2 gr/liter water), $\mathrm{D}_{1}$ (1 gr/liter of water) and $\mathrm{D}_{0}$ (Control). From the LSD results at the 0.05 level, it was known that the number of celery leaves in treatment D3 was significantly different from treatment $D_{2}, D_{1}$ and treatment $D_{0}$. This is presumably by giving foliar fertilizer at a dose of 3 gr/liter of water containing $\mathrm{N}, \mathrm{P}$ and $\mathrm{K}$ nutrients which is the right dose to spur better growth of celery.because at the time of plant growth elements $\mathrm{N}, \mathrm{P}$ and $\mathrm{K}$ are needed in larger quantities. Pinus and Marsono (2007) stated that the element nitrogen $(\mathrm{N})$ is very important for vegetative growth of plants because it can stimulate overall growth, especially stems, branches and leaves. Syafika (2014) adds that plants that are given proper nutrition can stimulate the growth of shoots and branches and have the potential to increase production. 


\section{d. Root Length and Fresh Weight Per Plant}

The results of analysis of variance showed that the concentration of foliar fertilizer growmorehad a significant effect on root length and had a very significant effect on fresh weight per plant. The average root length and fresh weight per plant of celery due to the concentration of foliar fertilizer growmoreare presented in Table 8 below.

Table 8. Average Root Length and Fresh Weight Per Celery Plant Due to Foliar Fertilizer

\begin{tabular}{|c|c|c|}
\hline $\begin{array}{c}\text { Concentration of Foliar } \\
\text { fertilizer }\end{array}$ & Root Length (cm) & Fresh Weight Per Plant (gr) \\
\hline $\mathrm{D}_{0}$ & $5.54 \mathrm{a}$ & $12.57 \mathrm{a}$ \\
\hline $\mathrm{D}_{1}$ & $5.88 \mathrm{a}$ & $14.40 \mathrm{ab}$ \\
\hline $\mathrm{D}_{2}$ & $6.11 \mathrm{a}$ & $15.04 \mathrm{~b}$ \\
\hline $\mathrm{D}_{3}$ & $7.20 \mathrm{~b}$ & $17.51 \mathrm{c}$ \\
\hline
\end{tabular}

Note: The numbers followed by the same letter in the same column are not significantly different in the LSD test at $5 \%$ level.

Table 8 shows that the data on average root length and fresh weight per celery plant due to the treatment of the highest concentration of foliar fertilizer growmore was obtained in treatment $\mathrm{D}_{3}$ (3 gr/liter water) followed by $\mathrm{D}_{2}$ ( 2 gr/liter water), $\mathrm{D}_{1}$ ( $1 \mathrm{gr} /$ liter of water) and $\mathrm{D}_{0}$ (Control). From the LSD results at the 0.05 level, it was known that the number of celery leaves in treatment $D_{3}$ was significantly different from treatment $D_{2}, D_{1}$ and treatment $D_{0}$. Minerals also maintain the stability of the shape and structure of the soil so that its component composition is not easily changed by the effects of changes and movements in the soil, so that it can support plants and provide space for life for the roots of plants and other living things in the soil. To get good fertility, soil treatment is also carried out. In general, sprinkling aims to improve soil structure and air circulation as well as providing basic fertilizers to improve the physical and chemical soil which will increase the fertility of the land we will use (Zailani, 2019).

It is thought that the increasing dose of foliar fertilizer up to $3 \mathrm{gr} /$ liter of water is the right dose to increase root length so that it can absorb nutrients which can increase the fresh weight per plant. According to Islam et al., (2012) the correct application concentration of foliar fertilizers was reported to be able to increase plant productivity by $59 \%$.

\subsection{The Effect of the Interaction of Giving Bio Fertilizer and Foliar Fertilizer on the Growth and Yield of Celery}

The results of the analysis of the variety of interaction treatments of the effect of giving bio fertilizers and the concentration of foliar fertilizer growmore showed a significant effect on the number of leaves parameters at the age of 40 and 60 days after planting and had no effect on other parameters.

The average number of leaves aged 40 and 60 days after planting due to the interaction effect of the effect of bio fertilizer and the concentration of foliar fertilizer growmore can be seen in Table 9 below.

Table 9. Average Number of Leaves at Age 40 and 60 Days after Planting due to the Effect of the Interaction between the Effect of Bio Fertilizer Application and the

Concentration of Foliar Fertilizer Growmore

\begin{tabular}{|c|c|c|}
\hline Combination Treatment & \multicolumn{2}{|c|}{ Number of Leaves } \\
\cline { 2 - 3 } & 40 days after planting & 60 days after planting \\
\hline $\mathrm{H}_{0} \mathrm{D}_{0}$ & $7.25 \mathrm{a}$ & $10.50 \mathrm{a}$ \\
\hline $\mathrm{H}_{0} \mathrm{D}_{1}$ & $7.63 \mathrm{ab}$ & $11.13 \mathrm{ab}$ \\
\hline $\mathrm{H}_{0} \mathrm{D}_{2}$ & $7.63 \mathrm{ab}$ & $11.38 \mathrm{abc}$ \\
\hline
\end{tabular}




\begin{tabular}{|c|c|c|}
\hline $\mathrm{H}_{0} \mathrm{D}_{3}$ & $8.88 \mathrm{bc}$ & $12.75 \mathrm{~cd}$ \\
\hline $\mathrm{H}_{1} \mathrm{D}_{0}$ & $7.75 \mathrm{ab}$ & $11.13 \mathrm{ab}$ \\
\hline $\mathrm{H}_{1} \mathrm{D}_{1}$ & $8.38 \mathrm{ab}$ & $12.13 \mathrm{bc}$ \\
\hline $\mathrm{H}_{1} \mathrm{D}_{2}$ & $8.88 \mathrm{bc}$ & $12.75 \mathrm{~cd}$ \\
\hline $\mathrm{H}_{1} \mathrm{D}_{3}$ & $10.38 \mathrm{~cd}$ & $14.63 \mathrm{ef}$ \\
\hline $\mathrm{H}_{2} \mathrm{D}_{0}$ & $8.63 \mathrm{~b}$ & $12.63 \mathrm{bcd}$ \\
\hline $\mathrm{H}_{2} \mathrm{D}_{1}$ & $10.38 \mathrm{~cd}$ & $15.00 \mathrm{ef}$ \\
\hline $\mathrm{H}_{2} \mathrm{D}_{2}$ & $11.25 \mathrm{de}$ & $16.13 \mathrm{fg}$ \\
\hline $\mathrm{H}_{2} \mathrm{D}_{3}$ & $12.13 \mathrm{ef}$ & $17.13 \mathrm{gh}$ \\
\hline $\mathrm{H}_{3} \mathrm{D}_{0}$ & $10.13 \mathrm{~cd}$ & $13.88 \mathrm{de}$ \\
\hline $\mathrm{H}_{3} \mathrm{D}_{1}$ & $13.63 \mathrm{~g}$ & $17.88 \mathrm{~h}$ \\
\hline $\mathrm{H}_{3} \mathrm{D}_{2}$ & $13.13 \mathrm{f}$ & $17.25 \mathrm{gh}$ \\
\hline $\mathrm{H}_{3} \mathrm{D}_{3}$ & $15.00 \mathrm{~h}$ & $20.75 \mathrm{i}$ \\
\hline
\end{tabular}

Note: The numbers followed by the same letter in the same column are not significantly different in the LSD test at $5 \%$ level.

The LSD test results in Table 9 show that the highest number of leaves at the age of 40 and 60 days after planting was found in the $\mathrm{H}_{3} \mathrm{D}_{3}$ treatment (bio fertilizer at a dose of 3.5 $\mathrm{m} /$ /liter of water and foliar fertilizer at a dose of $3.5 \mathrm{gr} / \mathrm{liter}$ of water) which was not significantly different from all treatments. The results showed that the interaction of the treatment of organic fertilizer with a dose of $3.5 \mathrm{ml} / \mathrm{liter}$ of water and foliar fertilizer with a dose of $3.5 \mathrm{gr} / \mathrm{liter}$ of water gave the best results on celery growth because this interaction was the right combination of treatments where the application of bio fertilizer with a dose of 3.5 $\mathrm{m} 1 /$ liter of water and foliar fertilizer at a dose of 3.5 gr/liter of water is able to supply the availability of nutrients in sufficient and balanced quantities for the growth of celery plants. According to Damanik (2010), the use of bio fertilizers in a sustainable manner is very important in increasing soil fertility, growth and crop yield.

\section{Conclusion}

From the results of the research and discussion above, it can be concluded that are as follows:

1. The concentration of bio fertilizers has a very significant effect on the height of 20 days after planting, 40 days after planting and 60 days after planting, the number of leaves aged 20 days after planting, 40 days after planting and 60 days after planting, the number of stalks aged 40 days after planting and 60 days after planting, root length and fresh weight per plant but did not significantly affect the number of stalks aged 20 days after planting. The best observation results were obtained in the $\mathrm{H}_{3}$ treatment $(3.5 \mathrm{ml} / \mathrm{l}$ water).

2. The concentration of foliar fertilizer has a very significant effect on the height of 20 days after planting, 40 days after planting and 60 days after planting, the number of leaves aged 20 days after planting, 40 days after planting and 60 days after planting, the number of stalks aged 40 days after planting and 60 days after planting and fresh weight per plant had a significant effect on root length but did not significantly affect the number of stalks aged 20 days after planting. The best observation results were obtained in the $\mathrm{D}_{3}$ treatment (3 gr/l water).

3. The interaction between the concentration of bio fertilizers and the concentration of foliar fertilizer has a significant effect on the number of leaves at the age of 40 and 60 days after planting but does not significantly affect the height growth of 20, 40 and 60 days after planting, the number of leaves aged 20 days after planting, the number of stalks aged 20, 40 and 60 days after planting, fresh weight per plant and root length. The best combination was obtained in the $\mathrm{H}_{3} \mathrm{D}_{3}$ treatment (bio fertilizer with a concentration of 3.5 $\mathrm{ml} / \mathrm{l}$ water and foliar fertilizer with a concentration of $3 \mathrm{gr} / \mathrm{l}$ water). 


\section{References}

Adji, S. 2007. Rancangan Percobaan Praktis Bidang Pertanian. Kanisius. Yogyakarta.

Andrian, D., Tantawi, A.R., and Rahman, A. (2019). The Use of Liquid Organic Fertilizer As Growth Media and Production of Kangkung (Ipomoea reptans Poir) Hydroponics Budapest International Research in Exact Sciences (BirEx) Journal Vol I (1): 23-34.

Bagus, $\underline{Z}$. 2011. Pupuk Hayati Tanotec. http://pupukhayati.wixsite.com/official/pupuktanotec. [Diakses 1 Desember 2017].

Damanik, M.M.B., B.E. Hasibuan, S. Fauzi, H. Hanum. 2010. Kesuburan Tanah dan Pemupukan. USU Press. Medan.

Dwidjoseputro, D. 1991. Pengantar Fisiologi Tumbuhan. Gramedia, Jakarta.

Harjadi, S. 2002. Pengantar Agronomi. Gramedia Pustaka Utama. Jakarta.

Noegraha, A. 2015. Penggunaan Pupuk Hayati Untuk Meningkatkan Pertumbuhan Dan hasil Tanaman Padi Sawah (Oryza sativa L.). Skripsi. Fakultas Pertanian. IPB. Bogor.

Pinus, L., Marsono, 2007. Petunjuk Penggunaan Pupuk. Penebar Swadaya. Jakarta.

Suharja. 2012. Growmore. http://kompos2.tripod.com/growmore.htm. [Diakses 1 Desember 2017].

Sunarjono, H,. 2011. Bertanam 30 Jenis Sayur. Penebar Swadaya. Jakarta.

Sundari, P. 2012. Pertumbuhan Tanaman Seledri (Apium graveolens L.) pada beberapa Jenis Media Tanam dan Dosis Pupuk Organik Cair. Skripsi. Program Studi Agroteknologi Fakultas Pertanian Universitas IBA. Palembang.

Suswati, et al. (2020). Integrated Control of Coffee Bean Borer (Hypothenemus Hampei) on Sigararutang Coffee, Motung Village, Ajibata SubDistrict, Toba Samosir District, Sumatera Utara. Budapest International Research in Exact Sciences (BirEx) Journal Vol 2 (1): 52-61.

Sutedjo, M. M. (2002). Pupuk Dan Cara Penggunaan. Rineka Cipta. Jakarta.

Syafika, M. 2014. Pengaruh pupuk daun terhadap hasil dan komponen hasil pucuk tanaman teh (Camellia sinensis L.). Jurnal Penelitian Teh dan Kina. 17 (2) : 47-56

Zailani, Kuswardani, R. A., and Panggabean, E. L. (2019). Growth Response and Crop Production (Brassica Juncea L.) Against Watering Time Interval at Various Hydroponics Media Budapest International Research in Exact Sciences (BirEx) Journal Vol I (1): 9-22. 